\title{
The discounted value of human lives lost due to COVID-19 in
}

\section{France [version 1; peer review: 2 approved]}

\author{
Joses Muthuri Kirigia (D1), Rose Nabi Deborah Karimi Muthuri (iD), \\ Lenity Honesty Kainyu Nkanata1, Newton Gitonga Muthuri ${ }^{3}$ \\ ${ }^{1}$ Department of Research, African Sustainable Development Research Consortium (ASDRC), Nairobi, Kenya
2Faculty of Health Sciences, University of Pretoria, Pretoria, South Africa
${ }^{3}$ Chandaria School of Business, United States International University - Africa, Nairobi, Kenya
}

V1 First published: 15 Oct 2020, 9:1247

https://doi.org/10.12688/f1000research.26975.1

\section{Abstract}

Background: This study estimates the total discounted value of human lives lost (TDVHL) due to COVID-19 in France as of 14 September 2020.

Methods: The human capital approach (HCA) model was used to estimate the TDVHL of the 30,916 human lives lost due to COVID-19 in France; i.e., assuming a discount rate of $3 \%$ and the national average life expectancy at birth of 83.13 years. To test the robustness of the estimated TDVHL, the model was rerun (a) using $5 \%$ and $10 \%$ discount rates, while holding the French average life expectancy constant; and (b) consecutively substituting national life expectancy with the world average life expectancy of 73.2 years and the world highest life expectancy of 88.17 years.

Results: The human lives lost had a TDVHL of Int $\$ 10,492,290,194$, and an average value of Int $\$ 339,381$ per human life lost. Rerun of the HCA model with $5 \%$ and $10 \%$ discount rates decreased TDVHL by Int $\$ 1,304,764,602$ (12.4\%) and Int $\$ 3,506,938,312$ (33\%), respectively. Re-calculation of the model with the world average life expectancy decreased the TDVHL by Int $\$ 7,750,187,267$ (73.87\%). Contrastingly, reestimation of the model with the world's highest life expectancy augmented TDVHL by Int\$3,744,263,463 (35.7\%).

Conclusions: The average discounted economic value per human life lost due to COVID-19 of Int $\$ 339,381$ is 8-fold the France gross domestic product per person. Such evidence constitutes an additional argument for health policy makers when making a case for increased investment to optimise France's International Health Regulation capacities and coverage of essential health services, and safely managed water and sanitation services.

Keywords

Coronavirus disease, COVID-19, France, Gross Domestic Product, Value of human life

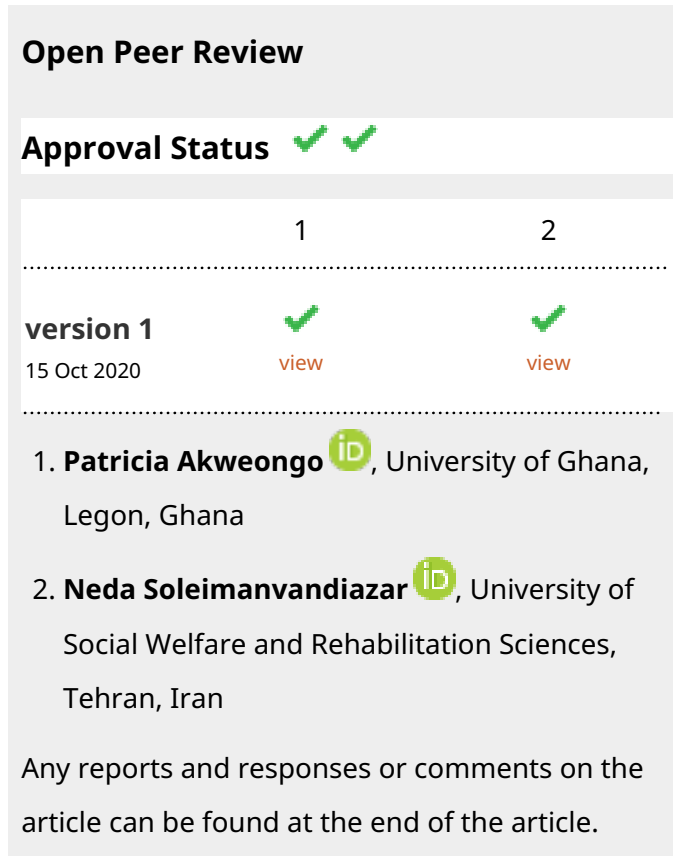

article can be found at the end of the article. 


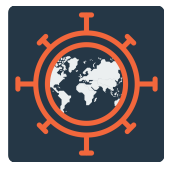

This article is included in the Emerging Diseases

and Outbreaks gateway.

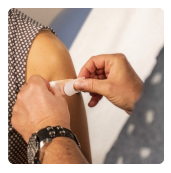

This article is included in the Sociology of

Health gateway.

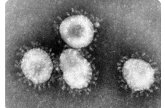

This article is included in the Coronavirus

collection.

Corresponding author: Joses Muthuri Kirigia (muthurijoses68@gmail.com)

Author roles: Kirigia JM: Conceptualization, Formal Analysis, Methodology, Writing - Original Draft Preparation; Muthuri RNDK: Data Curation, Formal Analysis, Methodology, Writing - Original Draft Preparation; Nkanata LHK: Data Curation, Formal Analysis, Methodology, Writing - Original Draft Preparation; Muthuri NG: Data Curation, Formal Analysis, Methodology, Writing - Original Draft Preparation

Competing interests: No competing interests were disclosed.

Grant information: The author(s) declared that no grants were involved in supporting this work.

Copyright: (c) 2020 Kirigia JM et al. This is an open access article distributed under the terms of the Creative Commons Attribution License, which permits unrestricted use, distribution, and reproduction in any medium, provided the original work is properly cited.

How to cite this article: Kirigia JM, Muthuri RNDK, Nkanata LHK and Muthuri NG. The discounted value of human lives lost due to COVID-19 in France [version 1; peer review: 2 approved] F1000Research 2020, 9:1247 https://doi.org/10.12688/f1000research.26975.1

First published: 15 Oct 2020, 9:1247 https://doi.org/10.12688/f1000research.26975.1 


\section{Introduction}

France is one of the seven major advanced economies (G7 countries). The country has an estimated population of 64.994 million; a total gross domestic product (GDP) of Int $\$ 3,161.335$ billion; and GDP per capita of Int $\$ 41,637.729$ in $2020^{1}$. In 2018, approximately $10,918,992(16.8 \%)$ of the population lived below France's poverty threshold of $€ 1,008$ per month of disposable income ${ }^{2}$. France has an inequalityadjusted human development index of 0.808 and a Gini coefficient of $32.7^{3}$.

By 14 September 2020, there were 29,182,605 coronavirus disease-19 (COVID-19) cases in the world, including 928,281 deaths, 21,027,161 recovered cases, and 7,227,163 active cases $^{4}$. Europe had a total of 4,080,753 COVID-19 cases, including 212,545 deaths, 2,245,583 recovered cases, and 1,622,625 active cases. On the same date, France had conducted a total of 10 million COVID-19 tests that revealed a total of 381,094 COVID-19 cases, which included 30,916 deaths, 89,059 recovered cases, and 261,119 active cases ${ }^{4}$. France bore $9.3 \%$ of total cases and $14.55 \%$ of total COVID-19 deaths in Europe. France's densities of 5,836 COVID-19 cases and 473 deaths per million population were higher than Germany's densities of 3,117 cases and 112 deaths per million population.

Four factors might explain the relatively large number of COVID-19 deaths sustained by France. First, there was more than two months' delay in country-wide implementation of public health interventions that could have prevented (or slowed) transmission and spread of severe acute respiratory syndrome coronavirus 2 (SARS-CoV-2). There is evidence that COVID-19 was already spreading in France by late December $2019^{5}$. However, the government only banned in mid-March 2020 gatherings of more than 100 people; the opening of nonessential public establishments; anchoring in inland and territorial waters of ships carrying more than 100 passengers; opening public establishments; opening schools and institutes of higher education; all religious gatherings; and embalming of dead bodies $^{6}$.

Second, the average of 13 International Health Regulations (IHR) core capacity score for France was 82 (on a scale of 0 to the target of 100) in $2019^{7,8}$, denoting an overall IHR capacity gap of 18 . As shown in Table 1, the country had IHR capacity gaps of 33 in legislation and financing, 20 in zoonotic events and the human-animal interface, 20 in food safety, 27 in laboratory, 20 in human resources, 27 in national health emergency framework, 7 in health service provision, 20 in risk communication, and 60 in points of entry ${ }^{9}$. The latter gap denotes suboptimal capacity at ports/airports/ground crossings for coordination and communication of pandemic surveillance; and appropriate medical diagnosis, isolation and care of ill travellers. The French points of entry capacity score of 40 were lower than the average score for the World Health Organization (WHO) European Region (EUR) of 61 by $52.2 \%$.

Second, as shown in Table 2, generally the health system indicators for France are better than the EUR averages.

\begin{tabular}{l|l|l}
\hline $\begin{array}{l}\text { Table 1. International Health Regulations (IHR) capacity scores in France in } \\
\text { 2019. }\end{array}$ & $\begin{array}{l}\text { France IHR } \\
\text { capacity } \\
\text { score }\end{array}$ & $\begin{array}{l}\text { WHO European } \\
\text { Region IHR } \\
\text { capacity score }\end{array}$ \\
\hline IHR capacities & 67 & 80 \\
\hline Legislation and Financing & 100 & 87 \\
\hline $\begin{array}{l}\text { IHR Coordination and National IHR Focal Point } \\
\text { Functions }\end{array}$ & 73 & 73 \\
\hline Laboratory & 100 & 84 \\
\hline Surveillance & 80 & 71 \\
\hline Human Resources & 73 & 73 \\
\hline National Health Emergency Framework & 93 & 73 \\
\hline Health Service Provision & 80 & 66 \\
\hline Risk Communication & 40 & 61 \\
\hline Points of Entry & 80 & 80 \\
\hline Zoonotic Events and the Human-animal Interface & 80 & 77 \\
\hline Food Safety & 100 & 69 \\
\hline Chemical Events & 100 & 77 \\
\hline Radiation Emergencies & $\mathbf{8 2}$ & $\mathbf{7 5}$ \\
\hline MEAN & & \\
\hline Source:WrdHeath Organizaton & 83 & \\
\hline
\end{tabular}

Source: World Health Organization? 
Table 2. Comparison of the health system and social determinants of health indicators in France with the World Health Organization European Region (EUR) averages.

\begin{tabular}{|c|c|c|}
\hline Health indicators & $\begin{array}{l}\text { Value in } \\
\text { France }\end{array}$ & $\begin{array}{l}\text { Average } \\
\text { value in EUR }\end{array}$ \\
\hline \multicolumn{3}{|l|}{ Health workforce indicators $(\mathbf{2 0 1 7})^{10,11}$} \\
\hline Medical doctors per 10,000 population & 32.67 & 34.1 \\
\hline Nursing and midwifery personnel per 10,000 population & 114.7 & 81.3 \\
\hline Dentists per 10,000 population & 6.67 & 5.7 \\
\hline Pharmacists per 10,000 population & 10.64 & 6.8 \\
\hline \multicolumn{3}{|l|}{ Medical devices indicators $\mathbf{s}^{10,11}$} \\
\hline Linear accelerators per million population (2013) & 7.4 & N/A \\
\hline Telecobalt units per million population (2013) & 0.11 & N/A \\
\hline Radiotherapy units per million population (2013) & 7.51 & 3.9 \\
\hline Magnetic Resonance Imaging per million population (2013) & 10.13 & N/A \\
\hline \multicolumn{3}{|l|}{ Infrastructure indicators ${ }^{10,11}$} \\
\hline Hospital beds per 10,000 population in 2018 & 59.1 & N/A \\
\hline \multicolumn{3}{|l|}{ Essential health service coverage indicators in $2017^{12}$} \\
\hline Universal health coverage index of service coverage (UHC SCI) & 78 & 77 \\
\hline $\begin{array}{l}\text { UHC SCI components: Reproductive, maternal, newborn and child } \\
\text { health }\end{array}$ & 96 & 86 \\
\hline UHC SCI components: Infectious diseases & 71 & 73 \\
\hline UHC SCI components: Non-communicable diseases & 56 & 61 \\
\hline UHC SCI components: Service capacity and access & 96 & 94 \\
\hline \multicolumn{3}{|l|}{ Catastrophic out-of-pocket health spending (SDG indicator 3.8 .2$)^{10,11}$} \\
\hline $\begin{array}{l}\text { Population with household expenditures on health greater than 10\% } \\
\text { of total household expenditure or income (SDG 3.8.2) in } 2010(\%)\end{array}$ & 1.42 & 6.27 \\
\hline $\begin{array}{l}\text { Population with household expenditures on health greater than 25\% } \\
\text { of total household expenditure or income (SDG indicator 3.8.2) in } \\
2010 \text { (\%) }\end{array}$ & 0.22 & 1.15 \\
\hline Current Health Expenditure (CHE) per Capita in Int\$ & $5,011.2$ & 2923 \\
\hline Domestic General Government Health Expenditure as \% of CHE & 77.09 & 65.0 \\
\hline Domestic Private Health Expenditure as \% of $\mathrm{CHE}$ & 22.91 & 35.0 \\
\hline Out-of-Pocket Expenditure as \% of CHE & 9.38 & 30.4 \\
\hline CHE as \% Gross Domestic Product (GDP) & 11.31 & 7.78 \\
\hline $\begin{array}{l}\text { Domestic general government health expenditure as percentage of } \\
\text { GDP (\%) }\end{array}$ & 8.72 & 4.92 \\
\hline \multicolumn{3}{|l|}{ Social Determinants of Health } \\
\hline Population using safely managed drinking water services $(\%)^{10,11}$ & 97.85 & 92 \\
\hline Population using safely managed sanitation services (\%) in $2017^{10,11}$ & 88.37 & 68 \\
\hline Total labour force unemployed (\%) & 8.431 & 7.6 \\
\hline
\end{tabular}


The density of 32.67 medical doctors per 10,000 population was lower than the average of 34.1 for EUR by $4.38 \%$. Nursing and midwifery personnel, dentists, and pharmacist densities in France were 29.12\%, 14.54\%, and 36.09\%, higher than EUR averages. The French density of radiotherapy units per million population of 7.51 was $48.07 \%$ higher than the EUR average. The current health expenditure (CHE) per capita of Int $\$ 5,011.2$ in France was $41.67 \%$ higher than the EUR average of Int $\$ 2,923$. The out-of-Pocket expenditure as a percentage of CHE of $9.38 \%$ in France was $224 \% \%$ higher than the EUR average of $30.4 \%$. The universal health coverage (UHC) service coverage index (UHC SCI) for France was 78\%, signifying a gap in coverage of essential health services of $22 \%$. The UHC SCI component of reproductive, maternal, new-born and child health; infectious diseases; non-communicable diseases; and service capacity and access had gaps of 4, 29, 44 and 4, respectively.

About $14,298,680(0.22 \%)$ of the population's health spending was higher than $25 \%$ of total household income, which reflects a very high risk of catastrophic and impoverishing health care expenditures. About $97.85 \%$ and $88.37 \%$ of the French population, respectively, use safely-managed drinking-water and sanitation services ${ }^{11}$; signifying that $1,397,371(2.15 \%)$ and 7,558,802 (11.63\%) people do not have access.

The type of economic evidence reported in this paper could be an essential input when health policy-makers make a case for increased investment in optimizing the IHR capacities, coverage of essential health services, and coverage of safely managed water and sanitation services to more effectively prevent and manage the current COVID-19 pandemic and future public health emergencies ${ }^{13-21}$.

A few macroeconomic studies have estimated the impact of the COVID-19 pandemic on business conditions in France ${ }^{22}$. However, there is a shortage of information on the value of human lives lost due to the pandemic. This study estimates the total discounted value of human lives lost (TDVHL) due to COVID-19 in France as of 14 September 2020.

\section{Methods}

\section{Ethical statement}

The study relied totally upon the analysis of secondary data contained in the International Monetary Fund (IMF), WHO, Worldometer, and Santé Publique France databases that are freely available to the public. Therefore, ethical clearance was not required.

\section{Study location}

This investigation of the value of human life was conducted on the cumulative number of persons who died of COVID-19 by 14 September 2020 in France. The study was a cross-sectional study. All the 30,916 COVID-19 people reported to have died from COVID-19 as of 14 September 2020 in France were included in the study.

\section{Human capital approach model}

This study applied the human capital approach (HCA), initially suggested by Adam Smith in $1776^{23}$, to estimate the monetary value of human life. The Organisation for Economic Co-operation and Development ${ }^{24}$ defines human capital as "The knowledge, skills, competencies and attributes (including stock of health) embodied in individuals that facilitate [the] creation of personal, social and economic wellbeing" (p.18).

Death from COVID-19 (or any other disease or injury) extinguishes the potential of a person to tap into one's stock of human capital either for personal development and enjoyment of leisure or to enhance societal cultural and socioeconomic wellbeing. A person's capacity for personal development, enjoyment of life (or flourishing) ${ }^{25}$, loving, religious practice, and performing expected societal roles ends upon death. It is also true that death halts individuals' spending on the consumption of goods and services, investments, government services (including payment of fees and taxes), and imports permanently. In other words, death terminates an individual's potential contribution to the creation of national output or GDP. Following the death of a human being at any stage of life, society losses not only the statistical person's contribution to GDP but also other intangible contributions, e.g. child's joy to parents, love to family and friends, companionship, fellowship, comradeship, sharing of knowledge (written or tacit) and social values.

Weisbrod $^{26}$ suggested measuring lost human capital as a result of premature death from any cause in terms of the deceased person's discounted future earnings net of their consumption ${ }^{26}$. In line with our past research ${ }^{13-21}$, the current study uses net GDP per capita (i.e. GDP per capita of France minus current health expenditure per person) to value human lives lost due to COVID-19 in France.

The TDVHL in France (TDVHL ${ }_{\text {FRANCE }}$ ) due to COVID-19 is the sum of DVHL among persons aged 0-14 years, 15-44 years, 45-64 years, 65-74 years, and 75 years and over ${ }^{13-21}$. Formally $^{13-21}$ :

$$
T D V H L_{\text {FRANCE }}=\sum_{i=1}^{i=5} D V H L_{i}
$$

Where: DVHL $_{\mathrm{i}}$ is the discounted value of human lives lost due to COVID-19 in $^{\text {th }}$ age group; $i=1$ is age $0-14$ years, $i=2$ is age $15-44$ years, $i=3$ is age $45-64$ years, $i=4$ is age $65-74$ years, and $i=5$ is age 75 years and over; $\sum_{i=1}^{i=5}$ is the sum of the discounted values of human lives lost in age groups denoted by number 1 to 5 .

The DVHL $_{\mathrm{i}}$ in each of the five age groups was calculated using the following formula ${ }^{13-21}$ :

$$
D V H L_{i}=\sum_{i=1}^{i=5}\left(\frac{1}{(1+1)^{t}}\right) \times\left(Y_{1}-Y_{2}\right) \times\left(Y_{3}-Y_{4}\right) \times\left(Y_{5}-Y_{6}\right)
$$

Where: $\sum_{t=1}^{t=n}$ is the sum from the first year of life lost $(\mathrm{t}=1)$ to the last years of life lost $(\mathrm{t}=\mathrm{n})$; $\mathrm{Y}_{1}$ is the GDP per capita of 
France; $\mathrm{Y}_{2}$ is the current health expenditure per person in France; $\mathrm{Y}_{3}$ is the average life expectancy at birth in France; $\mathrm{Y}_{4}$ is the average life expectancy at the onset of death in the $i^{t^{t h}}$ age group; $\mathrm{Y}_{5}$ is the total number of COVID-19 deaths in France as of 14 September 2020; $\mathrm{Y}_{6}$ is the proportion of total COVID-19 deaths borne by those in the $\mathrm{i}^{\text {th }}$ age group. The baseline for the analysis is 2020 .

\section{Data and data sources}

The data analysed in this paper and the sources are contained in Table 3.

\section{Data analysis}

The human capital model was analysed using Excel 2016 software (Microsoft, New York). The study reported in this paper replicates steps that were developed and applied in our recent valuation of human life studies related to COVID-19 $9^{13-15,17-21}$.

Step 1: Estimation of net GDP per capita (NGDPC) as the difference between per capita GDP (PCGDP) and current health expenditure per capita (CHEPC) for France. Thus, NGDPC = PCGDP - CHEPC $=($ Int $\$ 41637.729-$ Int $\$ 5011.20068359)=$ Int\$36,626.53.
Step 2: Estimation of the undiscounted years of life lost (UYLL) from COVID-19 in France between December 2019 and 14 September 2020.

(a) Calculation of average ages of onset of death (AAOD) from COVID-19 for each of the five age groups. This entailed taking simple averages for each age group, e.g. for AAOD for $0-14$ age group $=(0+14) / 2=7$ years.

(b) Calculation of YLL by one person who died of COVID-19 in the age group as the difference between national average life expectancy for France and the AAOD for the specific age group. For example, YLL by a person dead in the age group 0-14 years = national average life expectancy for France ( 83.13 years) minus AAOD for the group $(7$ years $)=$ 76.13 years. Thus, the YLL for one person who died in each of the five age groups was obtained similarly (see Table 4).

(c) Total UYLL in each age group = UYLL per deceased person in age group multiplied by the number of persons who died in an age group. For example, total UYLL in $0-14$ age group $=76$ years' x 4.5974025974026 persons dead $=349.40$ undiscounted YLL.

\section{Table 3. Data and data sources.}

\begin{tabular}{|c|c|c|}
\hline Variable & Data & Data sources \\
\hline $\begin{array}{l}\text { Per capita GDP in France } \\
\left(Y_{1}\right)\end{array}$ & Int $\$ 41,637.729$ & $\begin{array}{l}\text { International Monetary } \\
\text { Fund World Economic } \\
\text { Outlook Database }\end{array}$ \\
\hline $\begin{array}{l}\text { Per capita current health } \\
\text { expenditure in France } \\
\left(\mathrm{Y}_{2}\right)\end{array}$ & Int\$5011.20068359 & $\begin{array}{l}\text { World Health Organization } \\
\text { Global Health Expenditure } \\
\text { Database }^{27}\end{array}$ \\
\hline $\begin{array}{l}\text { Average life expectancy } \\
\text { at birth (ALE) in } 2020\left(Y_{3}\right)\end{array}$ & $\begin{array}{l}\text { France } A L E=83.13 \text { years; world ALE }=73.2 \text { years; Hong Kong female ALE } \\
\text { (world highest) }=88.17 \text { years }\end{array}$ & $\begin{array}{l}\text { Worldometer Life } \\
\text { Expectancy Database }{ }^{28}\end{array}$ \\
\hline $\begin{array}{l}\text { Average age at onset of } \\
\text { death }\left(Y_{4}\right)\end{array}$ & $\begin{array}{l}0-14 \text { years }=7 \text { years; } 15-44 \text { years }=29.5 \text { years; } 45-64 \text { years }=54.5 \text { years; } 65-74 \\
\text { years }=69.5 \text { years; and } 75 \text { years and over }=75 \text { years }\end{array}$ & Authors' estimates \\
\hline $\begin{array}{l}\text { Total number of human } \\
\text { lives lost from COVID- } \\
19 \text { in France by } 14 \\
\text { September } 2020\left(Y_{5}\right)\end{array}$ & 30,916 & $\begin{array}{l}\text { Worldometer France } \\
\text { COVID-19 Pandemic } \\
\text { database }^{4}\end{array}$ \\
\hline $\begin{array}{l}\text { Proportion of COVID-19 } \\
\text { deaths per age group in } \\
\text { France }\left(Y_{6}\right)\end{array}$ & $\begin{array}{l}0-14 \text { years }=0.000148706 ; 15-44 \text { years }=0.010905125 ; 45-64 \text { years } \\
=0.103747398 ; 65-74 \text { years }=0.179389313 ; \text { and } 75 \text { years and over }= \\
0.705809458 .\end{array}$ & $\begin{array}{l}\text { Santé Publique France } \\
\text { COVID-19: epidemiological } \\
\text { update of } 10 \text { September } \\
2020^{29}\end{array}$ \\
\hline $\begin{array}{l}\text { Proportion of COVID-19 } \\
\text { deaths per region and } \\
\text { territory in France }\end{array}$ & 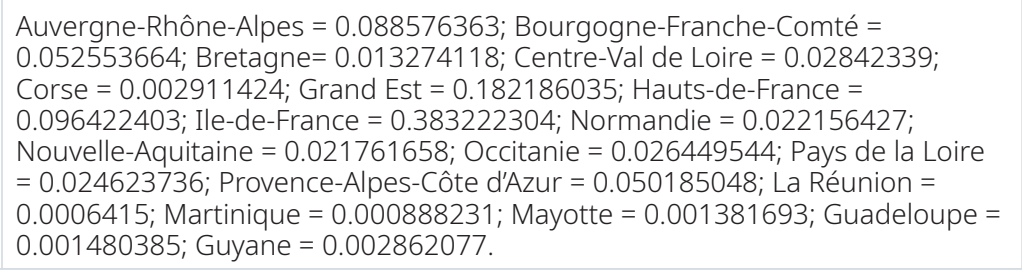 & $\begin{array}{l}\text { Santé Publique France } \\
\text { COVID-19: epidemiological } \\
\text { update of } 10 \text { September } \\
2020^{29}\end{array}$ \\
\hline Discount rate & $3 \%, 5 \%, 10 \%$ & $\begin{array}{l}\text { Related published } \\
\text { studies }^{13-21}\end{array}$ \\
\hline
\end{tabular}


Table 4. Undiscounted years of life lost per person due to COVID-19 in France by 14 September 2020.

\begin{tabular}{|c|c|c|c|c|c|}
\hline $\begin{array}{l}\text { Age group } \\
\text { (years) }\end{array}$ & $\begin{array}{l}\text { (A) Average life } \\
\text { expectancy at birth } \\
\text { in years in France }\end{array}$ & $\begin{array}{l}\text { (B) Average } \\
\text { age at onset } \\
\text { of death }\end{array}$ & $\begin{array}{l}\text { (C) Years of life } \\
\text { lost per person } \\
\text { in the age group } \\
{[\mathrm{C}=\mathrm{A}-\mathrm{B}]}\end{array}$ & $\begin{array}{l}\text { (D) COVID-19 } \\
\text { death by age } \\
\text { group }\end{array}$ & $\begin{array}{l}\text { (E) Total years of } \\
\text { life lost per age } \\
\text { group }[E=C \times D]\end{array}$ \\
\hline $0-14$ & 83.13 & 7 & 76 & 4.597402597 & 349.40 \\
\hline $15-44$ & 83.13 & 29.5 & 54 & 337.1428571 & $18,205.71$ \\
\hline $45-64$ & 83.13 & 54.5 & 29 & 3207.454545 & $93,016.18$ \\
\hline $65-74$ & 83.13 & 69.5 & 14 & 5546 & $77,644.00$ \\
\hline $75+$ & 83.13 & 75 & 8 & 21820.80519 & $174,566.44$ \\
\hline TOTAL & & & & 30,916 & $363,781.74$ \\
\hline
\end{tabular}

Step 3: Discounting of the years of life lost (DYLL).

(a) A discount rate of 3\% was chosen because it has been used in our previous COVID-19 related economic studies ${ }^{13-21}$, the economic evaluation of public health problems in Africa ${ }^{30}$, the World Health Report $2000^{31}$, the burden of disease ${ }^{32}$, and the World Bank Disease Control Priorities study ${ }^{33}$.

(b) Calculation of the discount factors applying the discount factor formula: $\left(\frac{1}{(1+r)^{t}}\right)$. The discount factor for first $\mathrm{YLL}=\left(\frac{1}{(1+0.03)^{1}}\right)=0.970873786407767$; discount factor for second YLL $=\left(\frac{1}{(1+0.03)^{2}}\right)=0.942595909133754$; discount factor for third YLL $=\left(\frac{1}{(1+0.03)^{3}}\right)=0.91514165935316$; ..., discount factor for the final YLL (which is 76.13 years for $0-14$ years $)=\left(\frac{1}{(1+0.03)^{7.13}}\right)=0.105772050189903$.

(c) Calculation of DYLL per deceased person in age group. DYLL in year $1=$ discount factor in year one $\times$ UYLL in year one $=0.970873786407767 \times 1=0.970873786407767$. DYLL in year $2=$ discount factor in year two $\times$ UYLL per person in year two $=0.942595909133754 \times 1=0.942595909133754$. DYLL in year $3=$ discount factor in year three $\times$ UYLL per person in year three $=0.91514165935316 \times 1=0.91514165935316$. DYLL in the last YLL (e.g. $76^{\text {th }}$ year for 0-14 years) = discount factor in $76^{\text {th }}$ year $\times$ UYLL per person in $76^{\text {th }}$ year $=$ $0.105772050189903 \times 1=0.105772050189903$.

(d) Estimation of total DYLL per deceased person in age group is equivalent to the sum of discount factors from year one to the last year of life.

(e) Total DYLL in each age group = DYLL per deceased person in age group multiplied by number of persons who died in age group. Therefore: UYLL in $0-14$ age group $=29.80759833$ $\times 4.597402597=137.04$ discounted YLL (see Table 5).
Step 4: Estimation of the total number of COVID-19 deaths in age group (COVID-19D $_{\mathrm{j}}$ ) equals the total number of COVID-19 deaths in France (TCOVID-19D) multiplied by the proportion (PROP) for that age group. For example, number of COVID-19 deaths in age group 0-14 years $=$ TCOVID-19D $\times$ PROP $=30,916 \times 0.000148706=4.597402597$. The number of COVID-19 for each age group are in Table 6.

Step 5: Estimation of the discounted economic value of human lives lost due to COVID-19 in each age $j^{\text {th }}$ group $=$ NGDPC $\times$ DYLL $_{j} \times$ COVID-19D. For instance, DVHL for age group $0-14=\operatorname{Int} \$ 36,626.53 \times 29.80759833 \times 4.5974025974026$ $=\operatorname{Int} \$ 5,019,209$.

Step 6: Calculation of the share of TDVHL accruing to the 13 regions and five territories of France $^{29}$ through multiplication of the TDVHL by proportion of COVID-19 deaths sustained by specific region and territory.

Step 7: A one-way sensitivity analysis was performed to evaluate the effect of changes in discount rate and the average life expectancy on the estimated TDVHL. This entailed recalculating the HCA model with (a) $5 \%$ and $10 \%$ discount $\operatorname{rates}^{13-21}$ and (b) the world average life expectancy of 73.2 years and the world highest average life expectancy of 88.17 years, i.e. the average life expectancy of Hong Kong women ${ }^{4}$. The model was reanalysed while holding all other parameters constant.

\section{Results}

The cumulative 30,916 human lives lost from COVID-19 by 14 September 2020 in France resulted in a total of 363,781.74 undiscounted years of life lost; which was equivalent to a total of $286,466.96$ discounted years of life lost.

Findings from the HCA model: assuming a national life expectancy of 83.13 years and a $3 \%$ discount rate Table 7 depicts the distribution by age group of the TDVHL of the 30,916 human lives lost due to COVID-19 in France by 14 September 2020. 
Table 5. Discounted years of life lost per age groups due to COVID-19 in France.

\begin{tabular}{|l|l|l|l|}
\hline $\begin{array}{l}\text { Age group } \\
\text { (years) }\end{array}$ & $\begin{array}{l}\text { (A) Discounted years of } \\
\text { life lost per life lost in } \\
\text { age group }\end{array}$ & $\begin{array}{l}\text { (B) COVID-19 } \\
\text { death by age } \\
\text { group }\end{array}$ & $\begin{array}{l}\text { (C) Total discounted } \\
\text { years of life lost per } \\
\text { age group [C = A x B] }\end{array}$ \\
\hline $0-14$ & 29.80759833 & 4.597402597 & 137.04 \\
\hline $15-44$ & 26.57766047 & 337.1428571 & $8,960.47$ \\
\hline $45-64$ & 19.18845459 & 3207.454545 & $61,546.10$ \\
\hline $65-74$ & 11.29607314 & 5546 & $62,648.02$ \\
\hline $75+$ & 7.01969219 & 21820.80519 & $153,175.34$ \\
\hline TOTAL & & $\mathbf{3 0 , 9 1 6}$ & $\mathbf{2 8 6 , 4 6 6 . 9 6}$ \\
\hline
\end{tabular}
Table 6 . Cumulative number of COVID-19 deaths per age group in France by
14 September 2020.

\begin{tabular}{|l|l|l|l|}
\hline $\begin{array}{l}\text { Age group } \\
\text { (years) }\end{array}$ & $\begin{array}{l}\text { (A) COVID-19 } \\
\text { deaths in France }\end{array}$ & $\begin{array}{l}\text { (B) Proportion } \\
\text { for age group }\end{array}$ & $\begin{array}{l}\text { (C) Number of deaths per } \\
\text { age group [C = A x B] }\end{array}$ \\
\hline $0-14$ & 30,916 & 0.000148706 & 4.597402597 \\
\hline $15-44$ & 30,916 & 0.010905125 & 337.1428571 \\
\hline $45-64$ & 30,916 & 0.103747398 & $3,207.454545$ \\
\hline $65-74$ & 30,916 & 0.179389313 & 5,546 \\
\hline $75+$ & 30,916 & 0.705809458 & $21,820.80519$ \\
\hline TOTAL & & & $\mathbf{3 0 , 9 1 6}$ \\
\hline
\end{tabular}

Table 7. Discounted value of human life losses linked to COVID-19 in France, using the national average life expectancy of 83.13 years and a discount rate of $3 \%$ (in 2020 Int\$).

\begin{tabular}{|l|l|l|}
\hline $\begin{array}{l}\text { Age group } \\
\text { (years) }\end{array}$ & $\begin{array}{l}\text { Discounted value of human life } \\
\text { losses at 3\% discount rate (Int\$) }\end{array}$ & $\begin{array}{l}\text { Average discounted value per } \\
\text { human life lost in an age group (Int\$) }\end{array}$ \\
\hline $0-14$ & $5,019,209$ & $1,091,749$ \\
\hline $15-44$ & $328,190,849$ & 973,447 \\
\hline $45-64$ & $2,254,219,824$ & 702,806 \\
\hline $65-74$ & $2,294,579,538$ & 413,736 \\
\hline $75+$ & $5,610,280,774$ & 257,107 \\
\hline TOTAL & $\mathbf{1 0 , 4 9 2 , 2 9 0 , 1 9 4}$ & $\mathbf{3 3 9 , 3 8 1}$ \\
\hline
\end{tabular}

The human lives lost to COVID-19 had a TDVHL of Int\$10,492,290,194, and an average value of Int\$339,381 per human life lost. Out of the TDVHL, $0.05 \%$ was borne by persons aged $0-14$ years, $3.13 \%$ by $15-44$ years, $21.48 \%$ by $45-64$ years, $21.87 \%$ by $65-74$ years, and $53.47 \%$ by 75 years and above. Around $46.48 \%$ of the TDVHL accrued to persons aged 15 and 74 years. The average TDVHL decreases with increase in age of the deceased, e.g. the average TDVHL for 0-14-year-olds is three-fold that of 75-year-olds and above.
Distribution of the total discounted value of human life by regions and territories. Figure 1 depicts the share of TDVHL across the 13 regions and five territories of France.

About $80.3 \%$ of the TDVHL accrued to only five regions of France, i.e. Auvergne-Rhône-Alpes, Bourgogne-Franche-Comté, Grand Est, Hauts-de-France, and Ile-de-France. Grand Est, Hauts-de-France, and Ile-de-France regions alone accounted for $66.18 \%$ of the TDVHL. The territories combined made up less than $1 \%$ of TDVHL. 


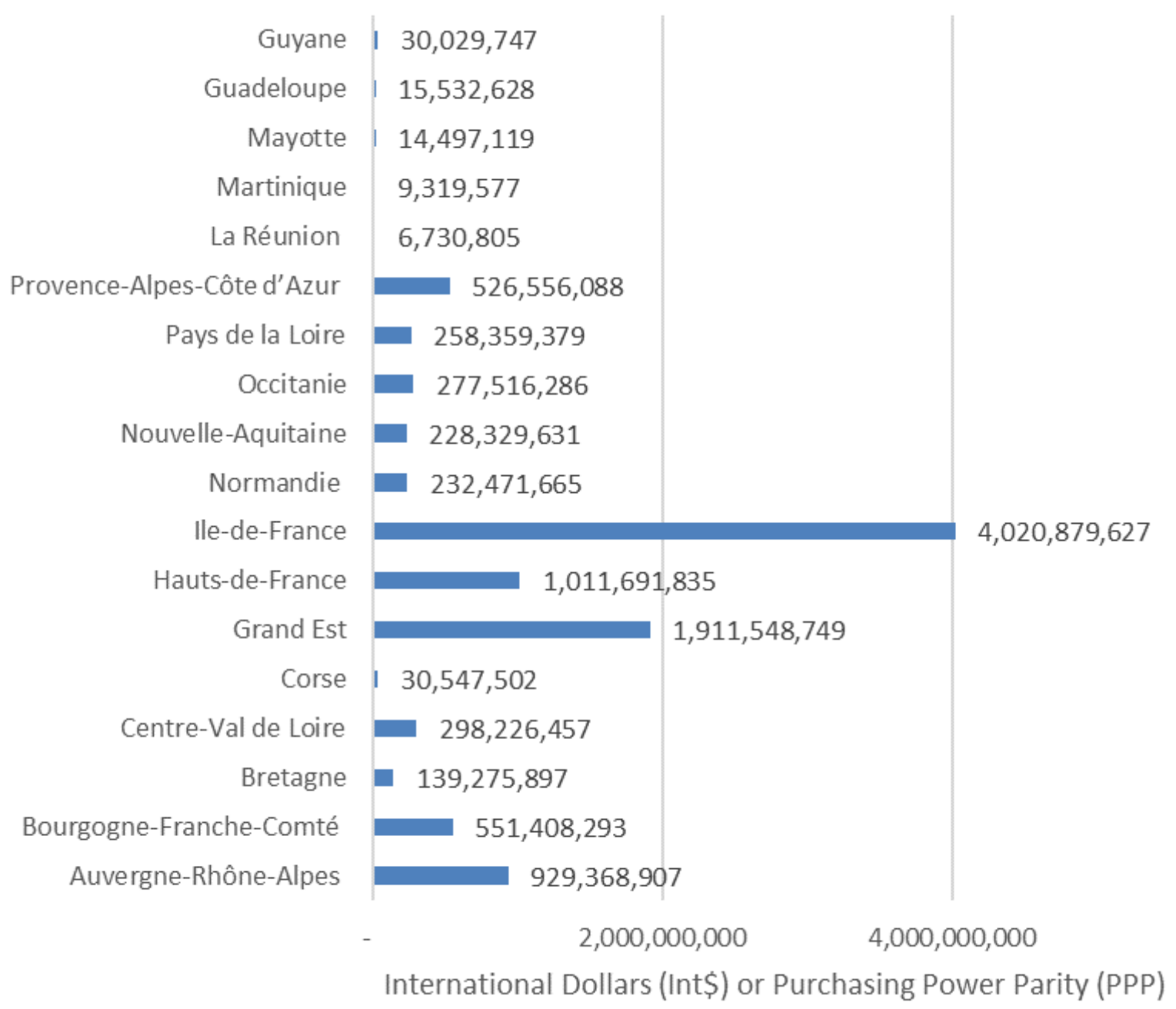

Figure 1. Regional and territorial distribution of the discounted value of human lives lost from COVID-19 in France as of 14 September 2020 (Int\$).

Findings from the HCA model: assuming $5 \%$ and $10 \%$ discount rates holding national life expectancy and other parameters constant

Table 8 presents the effects of the application of $5 \%$ and $10 \%$ discount rates on the TDVHL due to COVID-19 in France.

Rerun of the HCA model, alternately, with discount rates of $5 \%$ and $10 \%$ resulted in decreased TDVHL by Int $\$ 1,304,764,602$ $(12.4 \%)$ and Int $\$ 3,506,938,312(33 \%)$, respectively. The average values per human life lost declined by Int $\$ 42,204$ and Int $\$ 113,434$ in turn.

Findings from the HCA model: assuming the world and world's highest average life expectancies

Table 9 displays the impact on the TDVHL of substituting the national life expectancy with the world and world's highest average life expectancies.
Replacement of the national life expectancy of 83.13 years with the world average life expectancy of 73.2 years in the HCA model led to decreases in the total and average TDVHL of Int $\$ 7,750,187,267 \quad(73.87 \%)$ and Int $\$ 250,685$, respectively. Contrastingly, application of the world's highest life expectancy of 88.17 years augmented total and average TDVHL by Int $\$ 3,744,263,463(35.7 \%)$ and Int $\$ 121,111$

\section{Discussion}

Recap of key findings

- The 30,916 human lives lost to COVID-19 in France by 14 September 2020 had a TDVHL of Int $\$ 10,492,290,194$, which is equivalent to $0.332 \%$ of France's GDP.

- The average value was Int $\$ 339,381$ per human life lost, which is 8-times the GDP per capita for France in 2020. 
Table 8. Discounted value of human life losses linked to COVID-19 in France, using $5 \%$ and $10 \%$ discount rates (in 2020 Int\$).

\begin{tabular}{|l|l|l|}
\hline $\begin{array}{l}\text { Age group } \\
\text { (years) }\end{array}$ & $\begin{array}{l}\text { Discounted value of } \\
\text { human life losses at 5\% } \\
\text { discount rate (Int\$) }\end{array}$ & $\begin{array}{l}\text { Discounted value of } \\
\text { human life losses at 10\% } \\
\text { discount rate (Int\$) }\end{array}$ \\
\hline $0-14$ & $3,285,143$ & $1,682,665$ \\
\hline $15-44$ & $229,249,331$ & $122,765,261$ \\
\hline $45-64$ & $1,778,741,902$ & $1,100,721,858$ \\
\hline $65-74$ & $2,010,718,121$ & $1,496,400,572$ \\
\hline $75+$ & $5,165,531,095$ & $4,263,781,526$ \\
\hline TOTAL & $9,187,525,593$ & $6,985,351,882$ \\
\hline $\begin{array}{l}\text { Discounted value } \\
\text { per human life }\end{array}$ & $\mathbf{2 9 7 , 1 7 7}$ & $\mathbf{2 2 5 , 9 4 6}$ \\
\hline
\end{tabular}

Table 9. Discounted value of human lives lost from COVID-19 in France, assuming the world and world's highest average life expectancies (in 2020 Int\$ or purchasing power parity [PPP].

\begin{tabular}{|l|l|l|}
\hline Age group (years) & $\begin{array}{l}\text { Discounted value of human } \\
\text { lives lost using world } \\
\text { average life expectancy of } \\
\text { 73.2 years and 3\% discount } \\
\text { rate (Int\$) }\end{array}$ & $\begin{array}{l}\text { Discounted value of } \\
\text { human lives lost using } \\
\text { world highest average life } \\
\text { expectancy of 88.17 years } \\
\text { and 3\% discount rate (Int\$) }\end{array}$ \\
\hline $\mathbf{0 - 1 4}$ & $\mathbf{4 , 8 1 5 , 0 3 0}$ & $5,100,776$ \\
\hline $15-44$ & $299,500,807$ & $339,652,239$ \\
\hline $\mathbf{4 5 - 6 4}$ & $1,682,730,193$ & $2,482,524,318$ \\
\hline $65-74$ & $755,056,897$ & $2,909,603,712$ \\
\hline $75+$ & 0 & $8,499,672,611$ \\
\hline TOTAL & $2,742,102,927$ & $14,236,553,657$ \\
\hline $\begin{array}{l}\text { Discounted value } \\
\text { per human life }\end{array}$ & $\mathbf{8 8 , 6 9 5}$ & $\mathbf{4 6 0 , 4 9 1}$ \\
\hline
\end{tabular}

- Rerun of the HCA model with discount rates of $5 \%$ and $10 \%$ decreased TDEVHL by Int $\$ 1,304,764,602$ $(12.4 \%)$ and Int $\$ 3,506,938,312 \quad(33 \%)$, respectively.

- Reanalysis of the HCA model with the world average life expectancy dwindled the TDVHL by Int $\$ 7,750,187,267$ (73.87\%). Instead, a recalculation with the world highest average life expectancy of 88.17 years augmented TDVHL by Int $\$ 3,744,263,463$ $(35.7 \%)$.

Contrasting of study findings with those from other countries

The sensitivity analysis revealed that growth in discount rate triggers contraction in the TDVHL, and an upsurge in average life expectancy amplifies the TDVHL. The two findings are consistent with those of our previous studies conducted in Brazil $^{14}$, Canada ${ }^{15}$, China ${ }^{16}$, Germany ${ }^{17}, \operatorname{Iran}^{13}, \operatorname{Spain}^{18}$, Turkey $^{19}$, the United Kingdom $(\mathrm{UK})^{20}$, and the United States of America (USA) ${ }^{21}$.

The China ${ }^{16}$ and Spain $^{18}$ average values of Int $\$ 356,203$ and Int $\$ 470,798$ per human life loss associated with COVID-19 were $4.96 \%$ and $38.72 \%$ higher than the French average of Int $\$ 339,381$. On the other hand, the French average economic value per human life of Int $\$ 339,381$ was higher than those of Brazil of Int $\$ 99,629^{14}$, Canada of Int $\$ 231,217^{15}$, Germany of Int $\$ 132,960^{17}$, Iran of Int $\$ 165,187^{13}$, Turkey of Int $\$ 228,514^{19}$, the UK of Int $\$ 225,104^{20}$, and the USA of Int $\$ 292,889^{21}$ by $70.64 \%, 31.87 \%, 60.82 \%, 51.33 \%, 32.67 \%$, $33.67 \%$, and $13.70 \%$, in that order. Our previous studies 
have attributed the differences to variations in underlying population age distributions, the YLL, the GDP per capita, and the per capita health spending ${ }^{13-15,17-21}$.

\section{Practical implications of the study findings}

Evidence on the economic value of human lives losses associated with COVID-19 may be useful to the Ministry of Public Health when advocating within the Government of France for sustaining or increasing investments into the national health system, disease surveillance and response system (including IHR core capacities), and other systems (e.g. water and sanitation) that tackle social determinants of health in the pursuit of the United Nations Sustainable Development Goal 3 to "Ensure healthy lives and promote well-being for all at all ages" and Goal 6 to "Ensure availability and sustainable management of water and sanitation for all" (p.14) ${ }^{34}$. Of course, the economic evidence reported in this paper is meant to complement the International Bill of Human Rights obliging the Government of France to assure every citizen's realization of the right to life (Article 3) and to "...a standard of living adequate for the health and well-being of himself and of his family, including food, clothing, housing and medical care and necessary social services... (Article 25)" (p.76)

\section{Suggestions for further economic studies}

- Comprehensive studies on the multidimensional impact of COVID-19 on household's wellbeing.

- Wide-ranging studies on the multi-sectoral impact of COVID-19 pandemic once the pandemic is eradicated.

- Consumer choice behaviour analysis in respect to uptake of various COVID-19 prevention interventions, e.g. handwashing with soap, use of safely managed drinking water and sanitation, use of face masks, and patronage of alcohol bars during COVID-19.

- Economic evaluations of cost and consequences of preventive interventions (including personal hygiene, physical distancing, safely managed human waste disposal, contact tracing, vaccines), diagnostics, and potential treatments for COVID-19. Where feasible, cost-effectiveness, cost-utility, and costbenefit analyses ought to be designed and conducted alongside ongoing and envisaged clinical, and effectiveness randomized trials ${ }^{30,36}$.

\section{Limitations of the study}

First, HCA has been criticized for valuing non-market contributions to society at zero dollars ${ }^{37}$. For instance, traditional HCA values YLL among children below 14 years $^{38}$, retired
(62 years and above) $)^{38}$, homemakers (not employed outside the home), unemployed, and severely handicapped. In order to avoid discrimination against these vulnerable groups, which goes against the 1948 United Nations Universal Declaration of Human Rights ${ }^{35}$ and the Constitution of the World Health Organization $^{39}$, YLL at all the age groups were valued at equal net GDP per capita.

Second, the current study did not compare the costs and benefits of a raft of alternative preventive community-level interventions implemented by the French Government and citizens to limit transmission of COVID-19, e.g. bans on gatherings of more than 100 people, all religious gatherings, all travel, ships carrying more than 100 passengers, and embalming; closure of most public establishments, all schools and institutions of higher learning; and mandatory mask-wearing in public places $^{40}$. It was also outside the scope of the current study to appraise the costs and benefits of various options for diagnosis of COVID-19, contact tracing, quarantine, and management of persons who test positive for COVID-19 .

Finally, Stiglitz, Sen and Fitoussi ${ }^{41}$ have criticized GDP for not measuring economic wellbeing (or quality of life), ignoring income inequalities, and disregarding environmental damage caused by production processes.

\section{Conclusion}

The discounted value per human life loss of Int $\$ 339,381$ is 8 -fold the GDP per person of France. Such evidence constitutes an additional argument for health policy makers when making a case for increased investment to optimize IHR capacities, and coverage of essential health services, and safely managed water and sanitation services. The other rationales for increased investments in the development of resilient healthrelated systems include the fact that a pandemic, such as COVID-19, can trigger health systems and socioeconomic crises of significant magnitudes ${ }^{42}$; and also the fact that every human being has the right to life ${ }^{35}$.

\section{Data availability}

All data underlying the results are available as part of the article and no additional source data are required.

\section{Acknowledgements}

The authors owe deep gratitude to Jehovah Shalom for inspiration and sustenance during the life course of the study. The paper is dedicated to the citizenry and health workers in France for the chivalrous fight against COVID-19. The views expressed are exclusively those of authors and should not be attributed to institutions of affiliation. 
1. International Monetary Fund (IMF): World Economic Outlook Database. [cited 2020 May 13]. Reference Source

2. European Union: Relative at risk of poverty gap by poverty threshold - EUSILC and ECHP surveys. Eurostat. [cited 2020 May 15]. Reference Source

3. United Nations Development Programme (UNDP): Human Development Indices and Indicators 2018 Statistical Update. New York: UNDP; 2018. Reference Source

4. Worldometer: CoVID-19 Coronavirus Pandemic. [Last updated: September 14, 2020, 02:57 GMT]. [cited 2020 Sept 14]. Reference Source

5. Deslandes A, Berti V, Tandjaoui-Lambotte $Y$, et al.: SARS-CoV-2 was already spreading in France in late December 2019. Int J Antimicrob Agents. 2020 55(6): 106006.

PubMed Abstract | Publisher Full Text | Free Full Text

6. Wikipedia: COVID-19 pandemic in France. [cited 2020 Sept 14] Reference Source

7. World Health Organization [WHO]: World Health Statistics 2020: Monitoring health for the SDGs. Geneva: WHO: 2020.

Reference Source

8. World Health Organization [WHO]: IHR Core Capacity Monitoring Framework Questionnaire for Monitoring Progress in the Implementation of IHR Core Capacities in States Parties. Geneva: World Health Organization; 2017. Reference Source

9. WHO: Global Health Observatory data repository. International Health Regulations (2005) monitoring framework, SPAR. All capacities data by country. [cited 2020 Sept 14].

Reference Source

10. World Health Organization [WHO]: Global Health Observatory. Universa health coverage. [cited 2020 Sept 14]. Reference Source

11. World Health Organization [WHO]: World Health Statistics 2019: Monitoring health for the SDGs. Geneva: WHO; 2019. Reference Source

12. World Health Organization [WHO]: Global Health Observatory. Index of service coverage. [cited 2020 Sept 14]. Reference Source

13. Kirigia JM, Muthuri RNDK, Muthuri NG: The present value of human lives lost due to coronavirus disease (COVID-19) in the Islamic Republic of Iran. IOSR Jent Med Sci. 2020; 19(9): 45-53. Publisher Full Text

14. Kirigia JM, Muthuri RNDK, Nkanata LHK, et al.: The pecuniary value of human life losses associated with COVID-19 in Brazil. IOSR J Pharm. 2020; 10(8): 45-51. Reference Source

15. Kirigia JM: The dollar value of human life losses associated with COVID-19 in Canada. Pharm Biomed Res. 2020. (in press). Reference Source

16. Kirigia JM, Muthuri RNDK: The fiscal value of human lives lost from coronavirus disease (COVID-19) in China. BMC Res Notes. 2020; 13(1): 198. PubMed Abstract | Publisher Full Text | Free Full Text

17. Kirigia JM, Muthuri RNDK: The financial value of human life losses associated with coronavirus disease in Germany. Acad J Econ Studies. 2020. (in press).

Reference Source

18. Kirigia JM, Muthuri RNDK: The discounted money value of human lives lost due to COVID-19 in Spain. Journal of Health Research. 2020; 34(5): 455-460. Publisher Full Text

19. Kirigia JM, Muthuri RNDK, Nkanata LHK: The monetary value of human life losses associated with COVID-19 in Turkey [version 1; peer review: 2 approved]. Emerald Open Res. 2020; 2: 44. Publisher Full Text | Free Full Text

20. Kirigia JM, Muthuri RNDK: The present value of human lives lost due to COVID-19 in the United Kingdom (UK). Pharm Biomed Res. (in press). Reference Source

21. Kirigia JM, Muthuri RNDK: Discounted monetary value of human lives lost due to COVID-19 in the USA as of 3 May 2020. IOSR J Dent Med Sci. 2020; 19(5): $51-54$.

22. Banque de France: Update on business conditions in France at the end of 2020. Paris: Banque de France; 2020. Reference Source

23. Smith A: An inquiry into the nature and causes of the wealth of nations. 4th Edition. Edited by S.M. Soares. Lausanne: Metalibri Digital Library; 2007. Reference Source

24. OECD: The well-being of nations: the role of human and social capital. Paris: OECD; 2001 Reference Source

25. Culyer AJ: Commodities, characteristics of commodities, characteristics of people, utilities and the quality of life. In: The Humble Economist: Tony Culyer on Health, Health Care and Social Decision Making; Culyer, A.J., Cookson, R.A., Claxton, K.P. (Eds.); York Publishing Services Ltd, York, UK. 2012; 55-66. Reference Source

26. Weisbrod BA: The valuation of human capital.J Political Econ. 1961; 69(5): 425-436. Reference Source

27. World Health Organization [WHO]: Global Health Expenditure Database. [cited 2020 Sept 14]. Reference Source

28. Worldometer: Life Expectancy of the World Population. [cited 2020 Sept 14]; Accessed 14 September 2020 . Reference Source

29. Santé publique France: COVID-19: Point épidémiologique hebdomadaire du 10 septembre 2020. [cited 2020 Sept 16]. Reference Source

30. Kirigia JM: Economic Evaluation of Public Health Problems in sub-Saharan Africa. Nairobi: University of Nairobi Press; 2009.

Reference Source

31. WHO: The World health report 2000: health systems: improving performance. Geneva: WHO; 2000. Reference Source

32. Murray CJL: Quantifying the burden of disease: the technical basis for disability-adjusted life years. Bull World Health Organ. 1994; 72(3): 429-445. PubMed Abstract | Free Full Text

33. Jamison DT, Breman JG, Measham AR, et al:: Disease control priorities in developing countries. Oxford: Oxford University Press; 1993.

34. United Nations: Transforming our world: the $\mathbf{2 0 3 0}$ Agenda for Sustainable Development. General Assembly Resolution A/RES/70/1. New York: UN; 2015. Reference Source

35. United Nations: International Bill of Human Rights: A Universal Declaration of Human Rights. General Assembly Resolution A/RES/217 (III)A. New York: UN; 1948.

36. Drummond MF, Sculpher MJ, Torrance GW, et al: Methods for the economic evaluation of health care programmes (3rd Edition). Oxford: Oxford University Press; 2007.

37. Mooney GH: The Valuation of Human Life. Macmillan: London, UK. 1977.

38. French Republic: Code du travail (2014). [cited 2020 Sept 18]. Reference Source

39. WHO: Basic documents. Geneva: WHO; 2014. Reference Source

40. Wikipedia: COVID-19 pandemic in France. [cited 2020 Sept 18]. Reference Sourc

41. Stiglitz JE, Sen A, Fitoussi JP: Mismeasuring our Lives: why GDP doesn't add up. New York: The New Press; 2010. Reference Source

42. Maliszewska M, Mattoo A, van der Mensbrugghe D: The potential impact of COVID-19 on GDP and Trade: a preliminary assessment. Policy Research Working Paper 9211. Washington: World Bank Group; 2020. Reference Source 


\section{Open Peer Review}

\section{Current Peer Review Status:}

\section{Version 1}

Reviewer Report 28 April 2021

https://doi.org/10.5256/f1000research.29797.r83336

C 2021 Soleimanvandiazar $\mathbf{N}$. This is an open access peer review report distributed under the terms of the Creative Commons Attribution License, which permits unrestricted use, distribution, and reproduction in any medium, provided the original work is properly cited.

\section{Neda Soleimanvandiazar}

Preventive Medicine and Public Health Research Center, Psychosocial Health Research Institute, University of Social Welfare and Rehabilitation Sciences, Tehran, Iran

\section{Introduction:}

Comment: It would be better if the authors, in the introduction of the study explain the reason for the selection of 13 regions and 5 territories of France and as well how to select the desired regions (for example the features of these regions) that are given in the results section.

\section{Introduction: Paragraph 3}

Comment: The reason for the explanation of the four factors that caused the relatively large number of deaths due to COVID-19 sustained by France is not specified in the third paragraph by the authors.

\section{Methods: Step 3}

Discounting of the years of life lost (DYLL).

Comment: The authors mentioned that the 3\% discount rate was chosen because it has been used in our previous COVID-19 related economic studies, but it would be better to explain in a sentence about choosing a 3\% discount rate with reference (e.g. In European countries, the discount rate is usually considered $3 \%$, reference).

\section{Discussions}

Contrasting of study findings with those from other countries:

Comment: The discussion is not very well written. In the discussion, the authors merely cite the findings of the economic value per human life of their previous studies in this field and do not provide an explanation of the possible reasons for the differences in the economic value of human life between different countries. It is recommended that the discussion section of the article be upgraded.

Suggestions for further economic studies:

Comment: Some suggestions are not in line with the results of this study. 
Is the work clearly and accurately presented and does it cite the current literature? Partly

Is the study design appropriate and is the work technically sound?

Yes

Are sufficient details of methods and analysis provided to allow replication by others?

Yes

If applicable, is the statistical analysis and its interpretation appropriate?

Yes

Are all the source data underlying the results available to ensure full reproducibility?

Yes

Are the conclusions drawn adequately supported by the results?

Yes

Competing Interests: No competing interests were disclosed.

Reviewer Expertise: Health service utilization, Inequality in Health services, Inequality in Health, Social Determinants of Health, Social support, Social Network, Social Health in the Elderly, AIDS \& HIV, High risk Behaviors, Drug use and Substance use

I confirm that I have read this submission and believe that I have an appropriate level of expertise to confirm that it is of an acceptable scientific standard.

Reviewer Report 03 December 2020

https://doi.org/10.5256/f1000research.29797.r73179

(C) 2020 Akweongo P. This is an open access peer review report distributed under the terms of the Creative Commons Attribution License, which permits unrestricted use, distribution, and reproduction in any medium, provided the original work is properly cited.

\section{Patricia Akweongo}

Department of Health Policy, Planning and Management, School of Public Health, College of Health Sciences, University of Ghana, Legon, Ghana

Specific Comments for the revision of the paper

Introduction Paragraph 4 line 1: Second, the average of 13 International Health Regulations (IHR) core capacity score for France was 82 (on a scale of 0 to the target of 100) in 20197,

Comment: The authors estimate the average IHR core capacity score for France as 82 . It is unclear if this was an average of 13 items scored in Table 1 or how the authors estimated that. For 
summing up the 13 items in Table 1 under France the average is 74 instead of 82 ? This method for arriving at the 82 needs to be explained.

Introduction Paragraph 4 line 4-7: The French points of entry capacity score of 40 were lower than the average score for the World Health

Comment: This should read "The French points of entry capacity score of 40 was lower than the average score for the World Health"

Introduction Paragraph 4 line 4-7:

Comment: The authors indicate that France point of entry capacity score was 40 whereas that of EU was 61 representing 52.2\%. It is unclear how the authors arrived at this percentage (52.2\%)

Introduction: Paragraph 3-4

Comment: In paragraph 3 the authors mentioned four factors might explain the relatively large number of COVID-19 deaths sustained by France. The first being the more than 2 months delay with restrictions (Paragraph 3), the second being the IHR capacity scores (Paragraph 4) and then it repeats the second factor as in Table 2 as the general health system determinants. This is quite confusing as one loses track of the four factors that accounted for the state in which France found herself with respect to Cover-19. The authors will need to revise this to make it clear what these 4 factors are.

Introduction Paragraph 3 line 2

First, there was more than two months' delay in country-wide implementation of public health interventions that could have prevented (or slowed)

Comment: This should be revised to read "First, there was more than two months' delay in country-wide implementation of public health interventions that could have prevented or slowed " (since prevention is not the same as slowed)

\section{Methods}

Step 3: Discounting of the years of life lost (DYLL).

Comment:The authors indicate here that the discount of $3 \%$ is chosen based on their previous work but they cite other articles as references as well. Thus, the article should rather indicate that "(a) A discount rate of $3 \%$ was chosen because it has been used in previous COVID-19 related economic studies ${ }^{13-21}$,"

Step 6: Calculation of the share of TDVHL accruing to the 13 regions and five territories of France 29 through multiplication of the TDVHL by proportion of COVID-19 deaths sustained by specific region and territory.

Comment:In the introduction of the study it was not indicated that 13 regions and 5 territories of France will be used to show the share of these to the TDVHL. It thus pops up here with a previous mention of that in the introduction or even in the methods where information on the study site could be described. The characteristics of these territories may affect the outcomes of the study.

Step 7: A one-way sensitivity analysis was performed to evaluate the effect of changes in discount rate and the average life expectancy on the estimated TDVHL.

Comment: The authors chose to use the world average life expectancy and the world highest average life expectancy of 88.13 for women from Hong Kong for the sensitivity. Given that the authors began comparing France with the rest of EU, I was expecting that the authors will first 
conduct the sensitivity analysis using average life expectancy for the Europe before comparing with the rest of the world.

\section{Discussions}

Contrasting of study findings with those from other countries:

Comment:The authors refer only to their previous studies in comparing and contrasting their findings but I think the paper will benefit greatly by comparing and contrasting the findings with other studies in this same field as well.

Recap of findings

Reanalysis of the HCA model with the world average life expectancy dwindled the TDVHL by Int $\$ 7,750,187,267$

Comment:This should rather read" Reanalysis of the HCA model with the world average life expectancy reduced the TDVHL by Int $\$ 7,750,187,267$

\section{Limitations of Study}

For instance, traditional HCA values YLL among children below 14 years ${ }^{38}$, retired (62 years and above) ${ }^{38}$, homemakers (not employed outside the home), unemployed, and severely handicapped. Comment: This sentence above is incomplete with the use of "For instance....". Authors should consider revising this.

Second, the current study did not compare the costs and benefits of a raft of alternative preventive community-level interventions implemented by the French Government and citizens to limit transmission of COVID-19.

Comment: This sentence above should read "Second, the current study did not compare the costs and benefits of a raft of alternative community-level interventions implemented by the French Government and citizens to limit transmission of COVID-19.

General Comment:This paper highlights issues that might explain the years of lives lost due to Covid-19 in France that may appeal to policy makers to make great investments in interventions needed to reduce deaths lost and increase GDP. More elaborately in this paper is the clear and robust description of the analytical methods for calculating the lives lost. This step-by-step methodological approach could easily be replicated in many countries and sites to produce more evidence that will guide policy makers in the prioritizing investments in Covid-19 to curb the pandemic.

Is the work clearly and accurately presented and does it cite the current literature? Yes

Is the study design appropriate and is the work technically sound? Yes

Are sufficient details of methods and analysis provided to allow replication by others? Yes

If applicable, is the statistical analysis and its interpretation appropriate? Yes 
Are all the source data underlying the results available to ensure full reproducibility? Yes

Are the conclusions drawn adequately supported by the results?

Yes

Competing Interests: No competing interests were disclosed.

Reviewer Expertise: Health Equity, Economic Evaluation, Health Systems, Health financing, Human resource for health, malaria, gender and violence, etc

I confirm that I have read this submission and believe that I have an appropriate level of expertise to confirm that it is of an acceptable scientific standard.

The benefits of publishing with F1000Research:

- Your article is published within days, with no editorial bias

- You can publish traditional articles, null/negative results, case reports, data notes and more

- The peer review process is transparent and collaborative

- Your article is indexed in PubMed after passing peer review

- Dedicated customer support at every stage

For pre-submission enquiries, contact research@f1000.com 